Journal of Animal and Veterinary Advances 9 (6): 1005-1010, 2010

ISSN: $1680-5593$

(C) Medwell Journals, 2010

\title{
A Cost Effective Forklift for Materials Handling in Animal Production
}

\author{
Selçuk Arslan, Ali Aybek and Emrullah Baser \\ Department of Agricultural Machinery, College of Agriculture, \\ Kahramanmaras Sutcuimam University, Kahramanmaras, Turkey
}

\begin{abstract}
The objective of this study was to dimension, construct and determine the operational characteristics of a forklift to be used in materials handling in animal production and in other agricultural operations. A forklift with a load capacity of $600 \mathrm{~kg}$ was constructed, consisting of a single mast, single acting lift cylinder and a double acting tilt cylinder, to be mounted on a standard agricultural tractor. The minimum lift height is $1500 \mathrm{~mm}$ using the mast, whereas the maximum height is $2020 \mathrm{~mm}$ when the forklift is raised through the lifting arms of the three-point hitch of the tractor. Piston and fork speeds during lifting are 0.065 and $0.13 \mathrm{~m} \mathrm{sec}^{-1}$, respectively, while the lowering speeds are 0.11 and $0.22 \mathrm{~m} \mathrm{sec}^{-1}$. Lifting takes about $10-12 \mathrm{sec}$, while lowering takes about $6-8 \mathrm{sec}$. Static stability was maintained during tests at inclined concrete surfaces at the maximum capacity of $600 \mathrm{~kg}$ at vertical position of the mast. Assuming that most agricultural materials will be handled with loads less $600 \mathrm{~kg}$, the tractor (New Holland 60-56) forklift combination can operate safely both on horizontal and inclined road conditions without causing static or dynamic instability. The capacity of the system is about $10-11$ tons $\mathrm{h}^{-1}$ with loads of $200 \mathrm{~kg}$ at $50 \mathrm{~m}$ travel distance.
\end{abstract}

Key words: New Holland 60-56, forklift, stability, capacity, material handling

\section{INTRODUCTION}

Tractor-implement systems are of utmost importance, since the efficiency of agricultural operations is highly related with the tools powered by the tractor. There have been many functional improvements in tractors due to various types of operations needed in agriculture. Technical improvements and cost-effective operations of tractor-implement systems broadened the use of tractors and agricultural equipment throughout the world. As a consequence of wide-scale use of tractors and related implements, numerous benefits were brougth to agriculture (Alcock, 1986). Tractors and mechanization increases productivity, changes the nature of farm work by making, it less exhaustive and attractive as well (Liljedahl et al., 1996).

Human, however is not designed perfectly to be a power source and as a power source is limited to $<0.1 \mathrm{~kW}$ continuous power output. Thus human should not function as the primary source of power but should be controlling the power to increase the efficiency (Liljedahl et al., 1996). Nevertheless, farm work including loading, unloading and transporting to short distances are still heavily dependent on labor in small and mid-size farms in the developing world.

One of the most importand features of an agricultural tractor is the hydraulic power available to drive equipment attached to the tractor. Front loaders, skreypers and forklifts have found their places in agriculture for transporting agricultural products, such as granular materials, bales, feeds in sacks, fruit or vegetable boxes. A cost-effective, light-weight forklift that can be attachted to the three point hitch could be preferred and used efficiently by smaller farmers. Such a tractor-forklift system is needed to transport relatively small loads frequently encountered in farms to reduce the number of workers in fruit orchards and vineyards or during bale loading to trailers.

Efficiency can be increased in loading, lifting, transporting and stowing in all agricultural operations. Such operations particularly include loading and carrying bales, feed materials in bags in animal production and fruit and vegetable containers in horticultural harvest operations Forklift equipment can be used to handle pallet sized loads, which can be desirable during on-farm operations (Srivastava et al., 1994). The use of such equipment increases the total work hours of a tractor in a year, resulting in a decrease in costs of a tractor per hour and in more profitable machine operations (Hunt, 1995). Larger machines can complete the required work quickly, but when the timeliness is not taken into account, the smallest machines would be more economical due to low fixed and variable costs associated with small equipment (Srivastava et al., 1994).

Corresponding Author: Selçuk Arslan, Department of Agricultural Machinery, College of Agriculture, Kahramanmaras Sutcuimam University, Kahramanmaras, Turkey 
The objectives of this study were to construct a cost-effective forklift of $600 \mathrm{~kg}$ load capacity with a single mast and to determine the operational characteristics of the forklift that can be attached to the hitch of New Holland 60-56 agricultural tractor. The forklift was designed in its simplest form so that it can be affordable by small farmers.

\section{MATERIALS AND METHODS}

Dimensions of New Holland 60-56 agricultural tractor used in this study are shown in Fig. 1 and some technical properties are shown in Table 1.

Hydraulic power and lift test results for the three point hitch were taken from the tractor test reports. Hydraulic oil flow rate requirement was $17 \mathrm{~L} \mathrm{~min}^{-1}$ to raise the lift cylinder of the forklift at a speed of $0.1 \mathrm{~m} \mathrm{sec}^{-1}$. The pump flow rate and the corresponding pressure are sufficient to provide $600 \mathrm{~kg}$ lifting capacity.

Mechanical system: Mechanical system consists of a single mast to avoid lessen the cost of the forklift for the small farmer. The mechanical system comprised the forks, fork carrier, mast, lift chains and rollers (Fig. 2). The forklift was mounted on the three point hitch of the tractor.

Lifting capacity of the forklift depends on the load center. ISO 2328 and 2329 were used to determine the dimensions of the forks. According to the standard, load center should be $400 \mathrm{~mm}$ for loads up to 1 ton but may vary depending on the application, load and material selection. In this study, load center was chosen to be $525 \mathrm{~mm}$.

The mast was made of $10 \mathrm{~mm}$ thick steel sheets (U profiles), sufficient to support a load up to 1 ton. Fork carrier moves in the $U$ profile over roller bearings. Lift chains are supported by two rollers driven by the movement of the lift cylinder up and down. Design of individual machine elements, including rolling bearings, lift chains and sprockets, the mast and carrier was based on mechanical design and material selection principles (Childs, 2004; Ashby, 2007).

Hydraulic system: Two alternatives were considered for the hydraulic system in the study. First, a single acting lift cylinder was used and the tilt cylinder was not included in the system. In this system, there was no need for any supplemental hydraulic component but a hose to connect the quick coupling of the tractor to the lift cylinder. The cylinder is operated by the hydraulic lever of the tractor, which does not necessitate a directional control valve.

The second system included a double acting tilt cylinder in addition to the lift cylinder in the hydraulic system, along with the directional valves for both cylinders and pressure relief valve.

Stability: Center of gravity and stability of a tractorforklift system may be affected by many factors. Center of gravity keeps changing its position as the mast is tilted and when the tractor travels on different slopes or while

\begin{tabular}{lcll}
\multicolumn{4}{l}{ Table 1: Dimensions and technical properties of New Holland 60-56 } \\
$\begin{array}{l}\text { Dimension } \\
(\mathrm{mm})\end{array}$ & Values & Property & Values \\
\hline $\mathrm{R}(\mathrm{s})$ & 640 & Front track width ( mm) & $1450-1850$ \\
$\mathrm{~A}$ & 1705 & Rear track width (mm) & $1430-1930$ \\
$\mathrm{~B}$ & 2052 & Minimum toprak aralığ (mm) & 355 \\
$\mathrm{C}$ & 3565 & Front axle load (kg) & 735 (operator \\
& & & included) \\
$\mathrm{D}$ & 2345 & Rear axle load (kg) & 1401 \\
$\mathrm{E}$ & 2470 & & \\
$\mathrm{H}$ & 470 & & \\
F (front) & 1450 & & \\
$\mathrm{G}$ (back) & 1435 & & \\
\hline
\end{tabular}
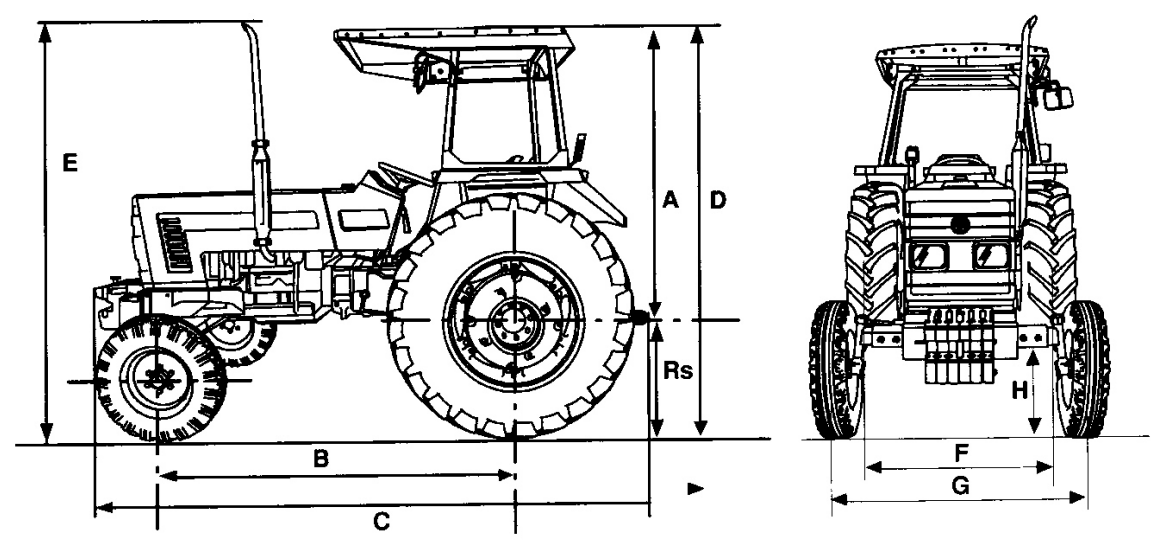

Fig. 1: General dimensions of New Holland 60-56 agricultural tractor 
J. Anim. Vet. Adv., 9 (6): 10051010 2010

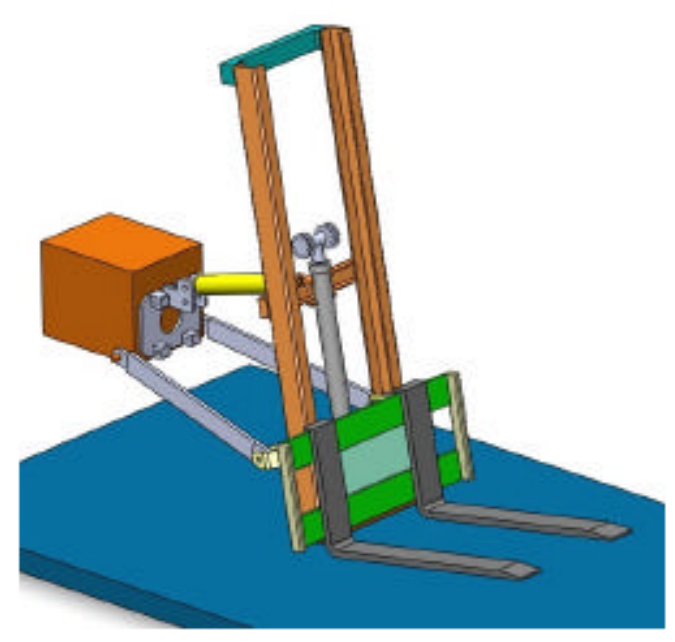

Fig. 2: F orklift without the tilt cylinder

the load is being lifted and lowered. In this study, the following experiments were conducted to asses the static and dynamic stability of the system:

Static tests: Stability tests on flat sufface and $2.5,6.5$ and $11.0^{\circ}$ inclined concrete road with differ ent loads $(200,300$, 400,500 and $600 \mathrm{~kg}$ ) at varying load centers $(400,500,600$, 700 and $800 \mathrm{~mm}$ ).

Dynamic tests: Stability tests on flat surface and on 2.5 and $6.5^{\circ}$ inclined concrete road with different loads $(100,200,300,400,500$ and $600 \mathrm{~kg})$ to observe the effect of sudden stops and take-offs.

Time consump tion: Time consumption was measured to load transport and unload various loads $(100,200$ and $600 \mathrm{~kg}$ over a distance of $50 \mathrm{~m}$ on a flat concrete with three replicates. Lifting and lowering times for em pty and loaded forks were measured and the corresponding hydraulic piston speeds were calculated.

\section{RE SULTS AND DISCU SSION}

Dimensions and operational features: Physical dimensions of the forklift are given in Table 2. Mast height is $1950 \mathrm{~mm}$ which is close to $\mathrm{m}$ ast height of the industrial forklifts. The lift height at tractor lift arms lowered position ( $1500 \mathrm{~mm}$ ) is limited due to the single mast system. A taller mast could be designed to obtain greater lifting heights, which may be more functional for some farm operations. Although, the lift height is limited with a single mast system, it is possible to stack various shaped agricultural materials to trailers and trucks commonly used for transportation. The single mast forklift
Table 2: Fysical dimensions of the tractor forklift-system with tilt cylinder

\begin{tabular}{|c|c|}
\hline Propert & Vabues \\
\hline Lift he ight (nm) & $\begin{array}{l}2020 \text { (lift ams fullyraise d) } \\
1500 \text { (lift ams lowered) }\end{array}$ \\
\hline Free lifthe ight (mm) & 0 \\
\hline Fork size (length, witth, thisloness (mm) & $1050 \times 100 \times 32$ \\
\hline Mast tilt amgle (de grees) & $\begin{array}{l}8^{\circ} / 20^{\circ} \text { (1ift arms fully raised) } \\
12^{\circ} / 22^{\circ} \text { (lift amm lowered) }\end{array}$ \\
\hline Overallwitth (mm) & $\begin{array}{l}1000 \text { (carrier) } \\
560 \text { (mast) }\end{array}$ \\
\hline Mast bwere dheight (mm) & 1950 \\
\hline
\end{tabular}

designed for the tractor eliminated longer lift chains, longer $m$ ast and additional relevant rollers that need to be used on dublex mast system. F or transporting heavier materials and stacking to greater heights, more costly and heavier solutions should be sought.

The load should be tilted rearward for transporting the loads on flat terraines and the tilt angle should be increased, when the tractor travels on upwards slopes. When a tilt cylinder is not incorporated into the system, the lift arms of the tractor should be used to raise the forklift to accomplish a safe tilt angle, which coprresponds to about $150-200 \mathrm{~mm}$ lifting of the mast from the ground level.

The maximum tilt angle using the lift arms to fully raise the forklift was found to be $12^{\circ}$ without the tilt cylinder and $20^{\circ}$ with the tilt cylinder. At the maximum tilt angle, the mast height is $2520 \mathrm{~mm}$ while the clearance from the ground is $570 \mathrm{~mm}$. Since, the loading and urloading should be done with no or small tilt angles, the stacking height is limited without a tilt cylinder and the tractor lift arms will not be functional to increase the lifting height but are useful for carrying the load safely on inclined terrains. A tilt cylinder allows the operator to fully raise the lift arms and then adjust the tilt of the mass as needed. Therefore, the lift height can be increased to $2020 \mathrm{~mm}$ with a tilt cylinder.

\section{Mechanical system}

Maximum allow able bad: New Holland $60-56$ has a mass of $2161 \mathrm{~kg}$ and maximum allow able load is $4350 \mathrm{~kg}$. The dead m ass of the forklift is $290 \mathrm{~kg}$ maximum load to be carried is $600 \mathrm{~kg}$, the mass of a pallet is about $20 \mathrm{~kg}$ and the mass of the operator is $80 \mathrm{~kg}$, resulting in a total mass of $3151 \mathrm{~kg}$. The total mass of the tractor-forklift combination is less than the maximum allowable load of the tractor.

Lifting and lowering $\$$ eeds: Lifting tim e varies between 11 and $13 \mathrm{sec}$, respectively for empty forks and $600 \mathrm{~kg}$ load capacity (Table 3). Forklift can be easily oper ated at the idle speed of the tractor engine. The lifting speed, however can be inceased by increasing the oil flow 1 ate. 
J. Anim. Vet. Adv., 9 (6): 1005-1010, 2010

Table 3: Lifting and lowering durations (sec) of different loads at idle engine speed-static test

\begin{tabular}{|c|c|c|c|c|}
\hline \multirow[b]{2}{*}{ Load (kg) } & \multicolumn{2}{|l|}{ Lifting } & \multicolumn{2}{|l|}{ Lowering } \\
\hline & Average & $\mathrm{SD}$ & Average & $\mathrm{SD}$ \\
\hline 0 & 10.89 & 0.18 & 8.44 & 0.20 \\
\hline 100 & 11.41 & 0.16 & 7.13 & 0.77 \\
\hline 200 & 11.75 & 0.27 & 6.89 & 0.45 \\
\hline 400 & 11.96 & 0.05 & 7.54 & 0.20 \\
\hline 600 & 12.92 & 0.14 & 6.80 & 0.64 \\
\hline
\end{tabular}

The lifting speed was measured to be 5 and $2.5 \mathrm{sec}$ at medium engine speed and maximum engine speed, respectively. Higher lifting speeds may be preferred for stacking small weights to increase the hourly capacity of the operation.

Fankhauser and Schiess designed a forklift for an agricultural tractor and suggested that the lowering duration should be about $10 \mathrm{sec}$. The lowering speed at higher capacities is faster and should be controlled by using the hydraulic lever of the tractor to control the lift cylinder. According to the observations during the experiments, lowering the load in $<7 \mathrm{sec}$ created difficulties in controlling the system and resulted in less stability during a sudden stop. This is especially true for operating on slopes. The lowering can be done slowly and hence better control can be accomplished when the operator gets familiar with the system.

Based on the lifting and lowering times and the piston stroke, the lift speed and lowering speeds of the forklift were calculated (Table 4). Lift speed is twice the piston speed, whereas the lifting height is twice the length of the piston stroke. Average lift speed decreases with increasing load and varied from about $0.07-0.06 \mathrm{~m} \mathrm{sec}^{-1}$, while the lowering speed increases with increasing load and varied from about $0.18-0.22 \mathrm{~m} \mathrm{sec}^{-1}$. The lowering speed was not proportional to load because the operator attempted to control the speed and was not sufficiently consistent in controlling the lowering speed. This will probably not observed as the operator gets acquinted with the system.

Stability of tractor-forklift system: Front axle load of the tractor is $735 \mathrm{~kg}$, corresponding to $34 \%$ of the total mass of the tractor. Static or dynamic load distribution changes as the forklift is mounted on the rear of the tractor. Front and rear axle loads were not measured under different loads and working conditions in this study. No stability problems were observed on flat surface up to maximum loading capacity $(600 \mathrm{~kg})$. The load center of the forks is $525 \mathrm{~mm}$, however, the tests were conducted with greater load centers as well. During the static tests on inclined roads, there were cases, where front load was not sufficient for steering. A load of $600 \mathrm{~kg}$ can be raised up to maximum height on $6.5^{\circ}$ slope at $600 \mathrm{~mm}$ load center
Table 4: Piston and fork speeds at idle engine speed $\left(\mathrm{m} \mathrm{sec}^{-1}\right)$ static test

\begin{tabular}{lcccc}
\hline & Lifting & \multicolumn{3}{c}{ Lowering } \\
$\begin{array}{l}\text { Load } \\
(\mathrm{kg})\end{array}$ & Piston speed & Lift speed & Piston speed & Lowering speed \\
\hline 0 & 0.069 & 0.138 & 0.089 & 0.178 \\
100 & 0.066 & 0.132 & 0.105 & 0.210 \\
200 & 0.064 & 0.128 & 0.109 & 0.218 \\
400 & 0.063 & 0.126 & 0.099 & 0.198 \\
600 & 0.058 & 0.116 & 0.011 & 0.220 \\
\hline
\end{tabular}

whereas static stability was lost as $600 \mathrm{~kg}$ load was placed at a load center of $700 \mathrm{~mm}$. Front axle load should be about $200 \mathrm{~kg}$ to maintain steering ability of the tractor. Since, the tractor should move slowly at the maximum height either to stack or unload materials from a stack, greater front axle load will be required under for dynamic operating conditions.

Static stability tests on $11.0^{\circ}$ slope demonstrated that $500 \mathrm{~kg}$ can be safely raised at $400 \mathrm{~mm}$ load center wherease the stability could be maintained only up to $350 \mathrm{~mm}$ height at load center of $550 \mathrm{~mm}$ with the maximum loading capacity.

Based on these tests, it was concluded that the forklift can be operated safely on flat terrains and small slopes with the maximum load at the designed load center of $525 \mathrm{~mm}$. If the load center must be increased due to the working conditions, the total load to be raised to maximum lift height should be decreased.

About $600-2200 \mathrm{~kg}$ capacity forklifts are in use and that $200 \mathrm{~kg}$ load is required at the front axle for practical purposes, which assures the maneuverability of the tractor-implement system. In this study, $120 \mathrm{~kg}$ front weight was used and no stability problems were observed. The potential instabilities can be overcome by using more front weight as the the slope and load center are to be increased.

Dynamic tests were conducted to draw general conclusions on the stability of the tractor-forklift system. The tractor can travel safely with the maximum load on $6.5^{\circ}$ slope provided that the forks are close to road during transportation. Front weight was not sufficient during backward travel with $600 \mathrm{~kg}$ load, $550 \mathrm{~mm}$ load center and $6.5^{\circ}$ slope and stability was difficult to maintain sudden stops.

Hydraulic system: The single acting hydraulic lift cylinder was operated by using the hydraulic lever of the tractor in the case that did not have a tilt cylinder. Consequenlty, no additional hydraulic system element was needed in the system except for a hydraulic hose. The lowering is done by the self weight of the forks and the carrier unless the forks are loaded with the material to be transported. Hydraulic lever can also be used to control the lowering speed, which eliminates the need for a directional valve or a flow control valve. 


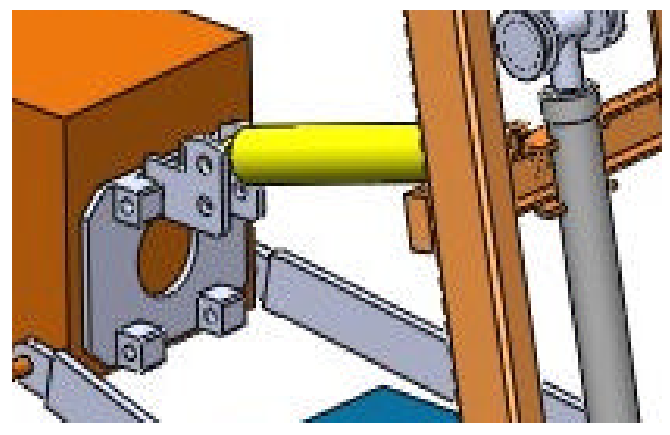

Fig. 3: L shaped support plate for connectirg the top linvelilt cyinder to the chaises of the tractor

Accordirg to tractor tes t reports, capacity of the lift amm at $18 \mathrm{MPF}$ is 11.74-1292 kw dependirg on the liftirg height. Considering the forklift self mas' (290 kg), maximum load capacity ( $600 \mathrm{~kg}$ ) and pallet mass (20 kg), approximately $8.7 \mathrm{kWN}$ is required to lift the forklift. I his suggests that the forklift can be easily raised and lowerd by the tractor lift amms.

Since, tractor usually operate on rough terains, high vibrotary forces may act on the tractor trough the top link of the three-point hitchwhen the forklift is to be used on rough surfaces over prolonges working hours. Ihe reaction forces on the top link, however, may be directed to the chaises of the trator rather than the hydranlics through the leaf sprire on which the top link is mounted. An L s haped support plate was added to the mecharical system to which the top link (or the tilt cyinder) was mounted to eliminate the forces that are transferred to the hydraulic system of the tractor to eliminate cortirual forces on tractor hydranlic sensirg system (Fig. 3). Ihis could be an important issue especially for fortlift of high load capacity.

When a tilt cyinder is added to the system, two directional control valves and a pressure corttol valve wers also incorporated into the system and the valve b bch was maunted on the chas is over the right rear tire of the tractor. Iractor oil flow rate was sufficient to operate both the lift cylinder and the tilt cyinder s imultameausly.

Time consumption: the most common gacioultural product to be transported and stacked are bales and boxes of finits or vegetables to a trailer or a truck. An averge rectargularb ale has a mas of 20-25 kp wheres mos of fnit boxes mayvary from 5-20 kg for 'small boxes and a few hundred he for carying fnit as a bulk material in a bin Considerirg $4-6$ bales or 10-12 fruit boxes, the fortlift load will be in the range of 100-250 kg for most applications for small famm enterpises.

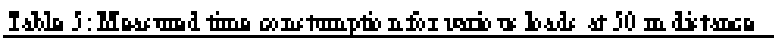
Iime $\infty \mathrm{Ir}$ meption is )

\begin{tabular}{|c|c|c|}
\hline \multirow[b]{2}{*}{ Los $(0 x)$} & \\
\hline & Awors $x$ & $\mathrm{RD}$ \\
\hline 100 & 74 & 5 \\
\hline 200 & $n$ & 1 \\
\hline 400 & 68 & 6 \\
\hline 600 & 69 & 12 \\
\hline
\end{tabular}

Iime consunption of the system was determined for a cycle of loadirg the forts on the ground level, tran porting the loads over $50 \mathrm{~m}$ distance at different ground speeds depending on the amount of load and and unloeding on the ground level.

Iiming was determined for stacling the pallets only for 200 le load capacity. The operator did not atteret to mairtain a corstant forwam speed for the tractor for each load, but varied the speed dependirg on the load beirg tamsported. Ihus, the transport speed reduced as the load increased durige the experiments (Iable S).

I he high variation in standart deviation might be atmouted to the unfamiliar tractor operator to the forklift operation. I he operator experienced neck pain and loss of attertion as a Ifsult of cortirmous work durige the experiments.

Ihe experiments were done contimously, Iesultirg in exkmstive work for the novice operator. Under usual field or fanm operations, less s trermaus work is likely, which nay not cause the same level of discorrfort.

Ihe time corsuretion for staching the loads was 65 sec for 200 h lo loeds over 50 m tramporatition distance, which approximately corresponded to a caparity of 10 tor $\mathrm{h}^{-1}$ for the tractor-fortlift system for tare porting the the loads already placed on pallets.

\section{CONCLUSION} follows:

Ihe Ifsults of this study could be surmmized as

- A tractor mourted forklift consisting of a single actirg lift cylinder and a double actirg tilt cylinder was tested in this study. Ihe forldift has a load capacity of $600 \mathrm{~kg}$ a mes's of $290 \mathrm{~kg}$, loed oenter of $525 \mathrm{~mm}$ and corr ists of a single rast to reduce the cost as much as possible

- Ite maximumfort hegight and the meximumlift height are $1950 \mathrm{rm}$ and $1500 \mathrm{~mm}$, res pectively when the tractor lift anms at lowered position. With the aid of lift anr of the tractor liftirg height canbe incresed up to $2020 \mathrm{rmm}$ 
- Lifting speed and lowering speeds were 0.065 and $0.13 \mathrm{~m} \mathrm{sec}^{-1}$, respectively depending on the load on the forks

- Maximum laod capacity of $600 \mathrm{~kg}$ can be safely lifted at load centers greater than the specified load center of $550 \mathrm{~mm}$ on flat surfaces and on terraines with small slopes

- On inclined roads up to $11^{\circ}$, static stability is maintained as long as the load center is not greater than $500 \mathrm{~mm}$ with the maximum load capacity

- This simple and cost-effective design can be effectively used for materials handling in animal production, such as bales and feed materials in bags and for transporting agricultural materials in containers

\section{ACKNOWLEDGEMENTS}

The researchers would like to thank to the Scientific Projects Management Office of Kahramanmaras Sutcuimam University for the support of this study (Project no. 2007/2-2).

\section{REFERENCES}

Alcock, R., 1986. Tractor-Implement Systems. AVI Publishing Co. Inc. Connecticut, USA., ISBN: 087055-522-7, pp: 161.

Ashby, M.F., 2007. Materials Selection in Mechanical Design. 3rdEdn., Elsevier Ltd., Oxford, UK., ISBN: 07506-6168-2, pp: 603.

Childs, P.R.N., 2004. Mechanical Design. 2nd Edn., Elsevier Ltd., Oxford, UK., ISBN: 0-7506-5771-5, pp: 358.

Hunt, D., 1995. Farm Power and Machinery Management. 9th Edn., Iowa State University Press, Ames, IA, USA., ISBN: 0813805821, pp: 288.

Liljedahl, J.B., P.K. Turnquist, D.W. Smith and M. Hoki, 1996. Tractors and Their Power Units. 4th Edn., ASAE Textbook, Michigan, USA., ISBN: 0-92935572-5, pp: 463.

Srivastava, A.K., C.E. Goering and R.P. Rohrbach, 1994. Engineering Principles of Agricultural Machines. Published by the American Society of Agricultural Engineers, Michigan, USA., ISBN: 0-929355-33-4, pp: 601 . 